\title{
PERFORMANCE CONTRACT (IMIHIGO) AND SOCIO-ECONOMIC DEVELOPMENT OF RWANDA: A CASE OF NYAMASHEKE DISTRICT (2014-2019)
}

\author{
ALINE INGABIRE \& Dr. RUVUNA ERIC \\ Kibogora Polytechnic
}

\author{
https://doi.org/10.37602/IJSSMR.2020.3405
}

\begin{abstract}
This study was conducted to assess the significance Performance Contract (Imihigo) on socio-economic development of Rwanda: A case of Nyamasheke District (2014-2019). The researcher has used both secondary data and primary data for assessing the study hypothesis. The researcher also used descriptive and correlative research design. Primary data were collected from 54 sampled staffs of Nyamasheke District. The study findings (secondary data) have been shown that $100 \%$ Nyamasheke district respect the format of Imihigo, Nyamasheke District also use national priorities, pillars for setting outcome, outputs, indicators sector by sector. In other case, indicators are well defined with clear baseline, targets, responsibilities and budget. These findings were used by the researcher to reject $\mathrm{H} 01$ "Nyamasheke District performance contracts (as a whole) and individual staff performance contracts are not well formulated". The assessment of H02 "Imihigo signed by District in last 6 years (2014-2019) on socio-economic development was poorly performed" also have revealed that Nyamasheke District ensures moderate performance in terms of imihigo evaluation. On the case of the economic pillar, this district was ranked good with more than $80 \%$ marks the same case for individual performance. This was resulted in the authority to the researcher for not accepting this hypothesis. Assessment again of secondary data has shown that Nyamasheke district is a poor performer in the real economy (the researcher use this as the difference of paper evaluation and field visit (visiting households one by one) as made by NISR through EICV5 and find that Nyamasheke District ranked the last (30th) in 30 districts in poverty reduction. Due to that, the researcher has accepted the H03. For the H04, the researcher has tested primary data (findings from the field) on the perception of respondents (District staffs) on both variables). Pearson correlation (r) is 0.210 meaning that, there is a weak positive correlation between imihigo (performance contract) and socioeconomic development. Sig. (2-tailed) is equal to 0.001 showing that, thus correlation resulted or signified by $\mathrm{r}$ is statistically significant. Thus, the researcher concludes that $\mathrm{H} 04$ is not accepted. Thus, evaluation of Imihigo may rank a district or a staff on good rank while on field people are suffering. A good ranking should be delivered from households looking changes they got in their living conditions with the support of local government authorities. In Other case performance contracts have a little (weak positive correlation) on socioeconomic development; it counts only $21 \%$ while the remaining $79 \%$ is from other factors not captured by this study.
\end{abstract}




\section{International Journal of Social Sciences and Management Review}

Keywords: Performance; Contracts; Social; Economic; Development

\subsection{INTRODUCTION}

After the most serious and violent conflict faced by Rwanda in the 20th century (1994 Genocide against Tutsi), the country is making a good and quick recovery in all sectors (political, social and economy). Development of the country after the 1994 Genocide against Tutsi was made as a joint initiative for both people (nationals and foreigners) together with the government of Unit and reconciliation, other governments and non-governmental organizations. But the main role was played by nationals and Rwandan Government of Unit and Reconciliation.

To achieve this, the government has initiated performance contracts as a tool for increasing the performance of authorities and population in general (Imihigo). Rwanda's performance contracts are binding agreements between government agencies and the President of the Republic for the former to reach certain targets on socio-economic development indicators (IPAR, 2016) and people (households) also has Imihigo notebook. This study focus on the agreements (imihigo) signed between local authorities the higher authorities (districts and ministry). Performance contract has started in 2006 and now cover most central and decentralized government agencies. Local authorities at district to cell levels are these working closely with the local population hands in hands for all policies and programme implementation of the government. In Rwanda, imihigo, also known as performance contracts, are signed between the president, local governments, and line ministries to achieve community targets. They play an integral role in the ability of the Rwandan government to deliver a better life for all. Imihigo reflect pre-colonial governance where each chief explains to the king what is planned to perform to his people (Daniel et al, 2014 ). The main purpose is to strive authorities and measuring the socio-economic achievements in a specific period, poor performers are advised in public. Based on this effort the country expects to become a middle-income country by 2024 (MINECOFIN, 2018). Thus, this study intends to evaluate the extent to which signing imihigo or performance contracts has boosted socio-economic development of Nyamasheke District in the last 5 years (2015-2020).

\subsection{BACKGROUND}

Imihigo is delivered from plural Kinyarwanda word of Umuhigo, which simply mean to vow to deliver. Imihigo also tends also to signify Guhiganwa, which means to work hard and achieve more compared to others in the same works. Imihigo is not a new concept as it describes the pre-colonial cultural practice in Rwanda where an individual sets targets or goals to be achieved within a specific period of time. The person must complete these objectives by following guiding principles and be determined to overcome any possible challenges that arise could be solved (IPAR, 2017).

As part of efforts to reconstruct Rwanda after 1994 Genocide against Tutsi, and nurture a shared national identity, the Government of Rwanda drew on aspects of Rwandan culture and traditional practices to enrich and adapt its development programs to the country's needs and context. The result is a set of Home-Grown Solutions culturally owned practices translated 


\section{International Journal of Social Sciences and Management Review}

into sustainable development programs. One of these Home-Grown Solutions is Imihigo which is still in use as a tool for encouraging and creating performers.

According to IPAR (2016) as published by World Bank (2017) Rwanda's extraordinary recovery to complete political, economic, and social collapse following the 1994 genocide against the Tutsi is one of Africa's most encouraging development success stories (Simeone, 2017). The Government of Rwanda (government of Unit and Reconciliation) has since committed to undertake a fundamental, broad-based economic and social transformation intended to shift the country from low to middle-income country's status, and this commitment has already yielded highly remarkable results. Rwanda is one of the few African countries that achieved most of the Millennium Development Goals (MDGs). Its real economic growth averaged $8 \%$ per annum from 2001 to 2015, which translated into significantly reduced poverty levels, from $56.7 \%$ in 2000 to $39.1 \%$ in 2014 , as well as a decline in extreme poverty levels from $35.8 \%$ in 2000 to $16.3 \%$ in 2014 (IPAR, 2016).

A key element of Rwanda's success is linked with the implementation of Imihigo, an ancestral cultural practice relating to performance contracts. The modernization of this practice is one of several innovative approaches being used to reinforce development planning, implementation, and evaluation towards improving living conditions for Rwandans (Odi, 2012). All levels of government including national, provincial, and district are required to plan and implement their own Imihigo commitments and targets (e.g. infrastructure development, job creation, etc.). These are informed by broader medium and long-term planning and budgeting processes, such as Rwanda's Vision 2020, the Economic Development and Poverty Reduction Strategy (EDPRS), sector-specific strategic plans, annual action plans, and the 5-year District Development Plans and the current underuse are NST1 (National Strategy for Transformation) and Vision 2050 (Jonathan, 2018).

\subsection{LITERATURE REVIEW}

District performance contracts (Imihigo) stand from the national goals (also delivered from international goals and domestic initiatives) which decentralized to local authorities. District imihigo is formulated as follows:

The pillars for district imihigo are (1) Economic transformation; (2) social transformation; and (3) Transformational Governance. Within each pillar, specific sectors are settled, under which outcomes per sector are defined, per each outcome outputs are defined and per each output, indicators are defined. For measuring this, each indicator has a baseline (defined in the clear source), targets (by quarters within a year), total annual target, activities and responsible personnel under each indicator and the end budget allocation is based on these activities (Nyamasheke, 2019).

Figure 1: Diagram for District Imihigo Structure 


\section{International Journal of Social Sciences and Management Review}

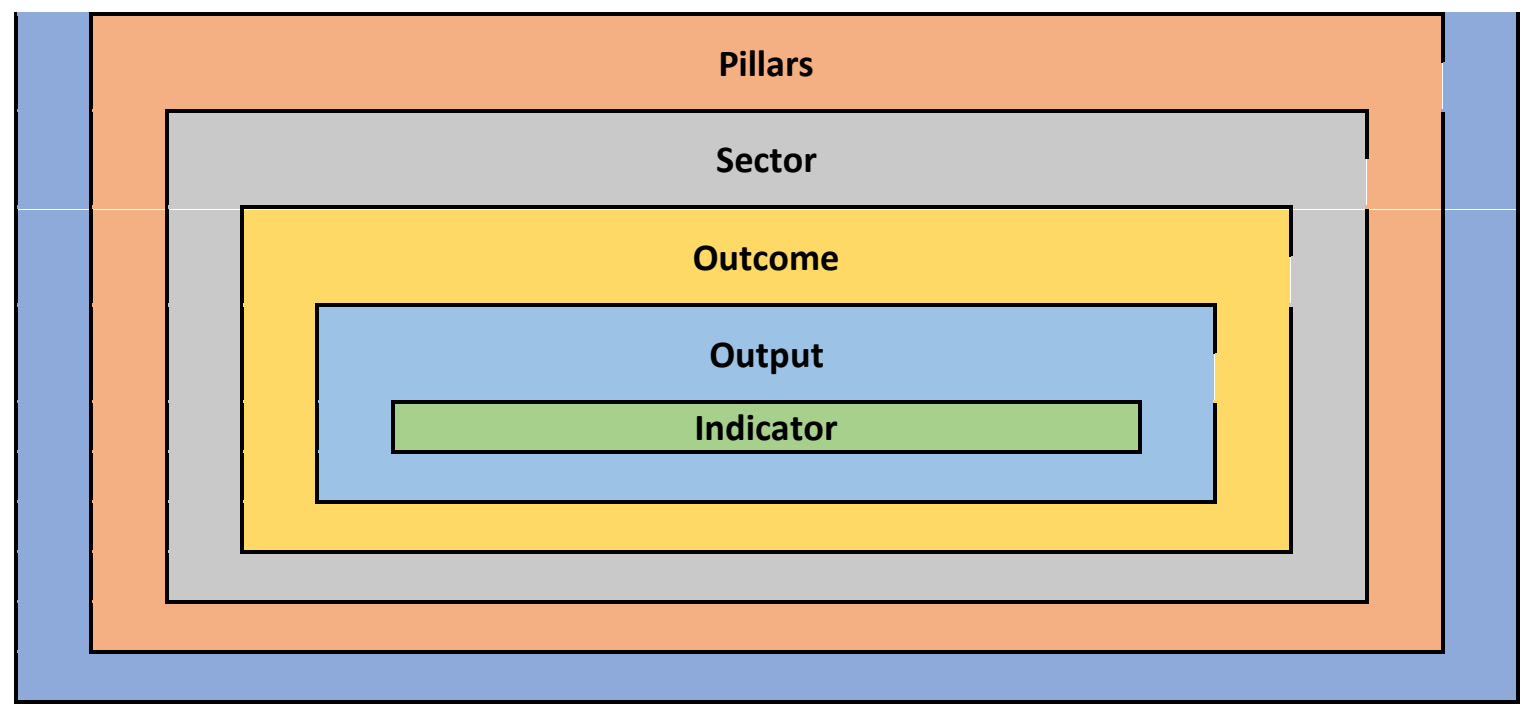

Source: (Nyamasheke, 2019)

\section{Preparation of performance contracts (Imihigo):}

Reference concept paper developed by Bruno Versailles (2012) here are identified four steps for Imihigo preparation: (1) National priorities identification by each line ministry to be implemented by local authorities under their guidance and this could be parallel with budget transfers to local authorities which signed to implement; (2) In local from government priorities are discussed and communicated to local government leaders; (3) District takes initiative with all stakeholders to develop these priorities and define them in the district development plan (five years range with annualized targets) and (4) final decentralized Imihigo and discussion of this draft to all stakeholders at all levels under district and QATT (Quality Assurance Technical Team) which ended by approval of Imihigo (Bruno, 2012).

Imihigo is not only signed by District officials because they are not alone in district. Districts sign performance contracts after that other central government institutions like line ministries also sign performance contracts with the President. After districts five levels (from the bottom-up): (a) Village, (b) Cell, (c) Sector, (d) districts and (e) Provinces and the city of Kigali. Unless otherwise indicated, this note deals with performance contracts at the district level, the most visible of the imihigo. "Imihigo is the cultural practice in the ancient tradition of Rwanda where an individual would set him/herself targets to be achieved within a specific period of time and do so by following some principles and having the determination to overcome the possible challenges" it is in that context even people in their households set annual Imihigo to be achieved and sets way to achieve them (Habamenshi et al, 2019).

\section{Socio-economic development indicators at District level:}

Reference to the essay of N'Kosi Craigwell-Walkes (2018) a given area is said socioeconomically developed when there are remarkable changes happened on people's per capita income (increased), creation of new opportunities in education, healthcare, employment in different economic sectors (agriculture, industry, services and transport). For example in each district of the country people are into four social-economic classes (Ubudehe categories) and 


\section{International Journal of Social Sciences and Management Review}

most of Imihigo takes a look to the last classes (1st Ubudehe category which composed by the very poor people in the district) for moving them from the 1st class to the 2 nd or the 3 rd but also if possible to the 4th Ubudehe class.

Decentralized to Nyamasheke District from the national level (Rwanda), agriculture occupies $70 \%$ of the total households and $75 \%$ of agricultural production is from smallholder farmers (RDB, 2019). With NST1 (1st National Strategy for Transformation 2018-2024), Rwanda needs to become a middle-income country with a knowledge-based economy. It is in that context the Imihigo in agriculture sector stand for land consolidation and growing modern crops with modern agriculture tools and technics use. This offer inputs to agro-processing industries. Looking socio-economic development in the district, the evaluators look different indicators to all sectors, for example, number of jobs created per economic sector, crops production, land consolidated, milk and meat production, health post or centres constructed, access to sanitation, performance against malnutrition, schools constructed and overall infrastructures, number of households and productive uses connected to electricity and with access to water, an increase of income per capita, and overall changes in social integration, etc.) (IPAR, 2017).

\subsection{THEORETICAL REVIEW}

Performance contract was delivered from contract theory which studies how economic actors can and do construct contractual arrangements, generally in the presence of asymmetric information. Because of its connections with both agency and incentives, contract theory is often categorized within a field known as Law and economics. One prominent application of it is the design of optimal schemes of managerial compensation (Letangule, 2012).

A performance contract is applied in management science for management control systems. It is a contractual arrangement for setting goals and ensuring arranged and easy management of goals implementors (Simiyu, 2012).

The theory of contract is concerned with the choice between a sales contract and an employment contract. The theory of incentives is concerned with a choice that is applicable to either type of contract, is looking of interest is on method for indirectly guiding the actions of the agent, a worker or a contractor (Kihara, 2013). Yawell formulates a general decisiontheoretic incentive model and investigates its properties under sets of assumptions, including certainty and uncertainty. The incentives relationship he studies includes only two parties. This relationship is further simplifying for purposes of analysis so that the payoff to the principal results exclusively from the action of the agent, while the agent's reward is determined solely by the principal according to the perceived results of the agent's actions. Yawell assumes that the basic relationship between the two parties is formed for the benefits of both and investigates the extent to which the principal can guide the agent's actions by establishing rewards conditional on the results the agent achieves. This is similar to the way Imihigo or performance contracts in Rwanda are underutilized toward socio-economic development. It is mandatory to the employee to achieve contracts and the best are getting a reward (not mandatory) but the poor performers decide themselves to resign (Kogei et al, 2013). 


\section{International Journal of Social Sciences and Management Review}

It is difficult for management and control of public interests' activities which are managed by people who work for monthly income and work for personnel or family interests. Supervision from ministries to districts and from districts to villages need inter coordination which could be evaluated easily rather than making daily checkup. That's why contract theory selected to be linked to performance contract management which is being assessed by this study on its significance on socio-economic development. Looking initiatives created by signing performance contract on socio-economic development. This is due to the fact that performance contract is communicated to the population, are evaluated in public and poor performers get punishment clear to everyone (MINECOFIN, 2018).

\subsection{STUDY GAP}

In his study Habamenshi et al, (2019) on the contribution of Imihigo on the socioeconomic development in Rwanda (2013-2018) a case study of Gakenke District, by using a mix of quantitative and qualitative approaches whereby primary data were collected using questionnaire, interview, focus group discussions, personnel observations and telephone calls; and secondary data were collected using archival review. The findings explain that signing Imihigo for district authorities has improved agricultural techniques that increased the production which in turn improved the lives of the citizens and reduced hunger (affirmed by $100 \%$ of respondents); New forest and trees planted and soil protection against erosion and increased agricultural productivity (affirmed at 100\%). Signing Imihigo contributed to the improvement of new roads and the creation of new roads (affirmed at 97\%); signing Imihigo contributed to the increase of access to electricity (70\%). Signing Imihigo system resulted in the creation of new jobs (72\%) (Habamenshi et al, 2019); Cooperatives were improved (affirmed at 69\%); Imihigo improved the lives of poorest households through social protection programs namely VUP and Girinka (affirmed at 100\%); education sector was improved by new classrooms constructed (affirmed at 100\%); Signing Imihigo implemented mechanisms reducing dropouts together with school feeding (affirmed at 86\%); Imihigo system improved health care services (affirmed at 90\%). Challenges outlined by the research include limited budget allocated to infrastructure, fertilizers, BDF (Business Development Funds), VUP (Vision 2020 Umurenge Program) and Girinka (Habamenshi et al, 2019).

According to the National Institute of Statistics (NISR, 2018), imihigo is one of the homegrown solutions embarked on by the Government of Rwanda to solve some of the most pressing challenges that the country faces. It creates the ability to Rwandans to take part in their own development and aspirations. Rwandans access their own problems and take initiatives for solving them without thinking of external support. This is the logic and spirit that has been driving Imihigo Performance Contracts since 2006 (NISR, 2018). These contracts, signed between ministers, district mayors, senior executives of selected Boards (parastatals) with the Head of State, aim at improving Rwandans living conditions. Consequently, Imihigo is a tool for accelerating the ambitions that have been set by the leadership of the country that are geared towards meeting the expectations that the people of Rwandan have for their leaders enshrined in national strategic plans (NISR, 2018).

Learning from EICV5 (NISR, 2018) poverty rate in some districts, most notably Kicukiro, Nyarugenge, and Gasabo, is relatively low (below 15\%), while in some it is very high, reaching close to $70 \%$ in Nyamasheke. Nyamasheke District is the first district reported in 


\section{International Journal of Social Sciences and Management Review}

Rwanda as a poorest district (with a high rate of poor people) in 2013/14 around 62\% which increased to $70 \%$ in $2016 / 17$ (NISR, 2018). This poor performance was marked while employees coted good performance in terms of the performance contract. According to imihigo evaluation report 2017/2018 published by NISR, it is stated that "The performance of Nyamasheke District on Imihigo has relatively declined in terms of improvement for over the last three years. In FY2015/2016, it was ranked 9th while in the Financial year 2016/2017, it was ranked 11th and 17th in this financial year 2017/2018 respectively with $67.1 \% \%$ in the overall performance". Thus, the gap is how in the same period in Imihigo Nyamasheke was ranked 17th while in a survey on poverty ranked indicators ranked the last among 30 districts from 2013 to 2017 (NISR, 2018). However, they are several indicators to be considered while evaluating Imihigo and poverty is the main indicator covering more others for assessing socio-economic development. It is in that context; the researcher intends to assess the contribution of performance contract (Imihigo) to the socio-economic development of Nyamasheke District (2015-2019).

\section{Figure 1: Conceptual framework}

\begin{tabular}{|c|c|}
\hline $\begin{array}{l}\text { Setting Imihigo and Evaluation: } \\
\text { - Prionities of government; } \\
\text { - Setting outcome, outputs from } \\
\text { national pillars in each sector. } \\
\text { - Define indicators and baseline; } \\
\text { - Define period and define } \\
\text { responsible person for each } \\
\text { activity; and } \\
\text { - Define required budget for each } \\
\text { activity; }\end{array}$ & $\begin{array}{l}\text { Socio-Economic Development: } \\
\begin{array}{l}\text { - Infrastructure development; } \\
\text { - Poverty reduction; } \\
\text { - Increase of Jobs; } \\
\text { - Education development; } \\
\text { - Health Sector Development; } \\
\text { - Improve sanitation; } \\
\text { - Socialintegration. }\end{array}\end{array}$ \\
\hline
\end{tabular}

Source: Researcher, 2020

As seen from the above figure and defined in the literature review, national priorities are decentralized to the district. To define district imihigo there defined into outcomes pillar by pillar, each outcome also defined into output, and from each output, indicators are defined with clear (with source) baseline. For each indicator, targets are settled (total annual disaggregated into quarterly targets) and activities per each which later facilitate to estimate targets. Each employ within District set Imihigo delivered from District Imihigo. For measuring the achievement of District Imihigo each indicator is evaluated looking at the achievement level (in the form of a percentage). District Imihigo performance on side of socio-economy are measured in terms of number of infrastructures developed, number of households secured from poverty (this include change in income, crops and animal production, etc), number of jobs created, education development, health services to the population, sanitation (quality of toilet and access to water) and achievements in people's opinions and association via unit and reconciliation and working together in cooperatives.

\subsection{METHODOLOGY}

\subsection{Area of the study}




\section{International Journal of Social Sciences and Management Review}

Nyamasheke district is one among 7 districts of Western Province (Rwanda), it has 15 sectors, 68 cells and 588 villages. Nyamasheke district has surface area of 1,174-kilometer square with 412,352 population (Murangwa, 2014). The average size of the household for Nyamasheke district is 4.9 persons, which is the same as for Western Province. It is slightly higher than the national average (4.8). Nyamasheke district has 123 females per 100 males, which is above the national average of 111 females; Nyamasheke is ranked first country-wide on this indicator (Murangwa, 2012).

\subsection{Research design}

This study is a descriptive design and correlational design. It is descriptive as the researcher gives description of Nyamasheke District employees and their Imihigo structure. This study also describes the socio-economic indicators which are observed as results of Imihigo signing (performance contracts). This study also is correlative as it intends to analyse the correlation between performance contract and socio-economic development of Nyamasheke District.

\subsection{Population}

Primary data of this study was collected from District employees who used to sign a performance contract with District mayor (individual performance contracts) which are in line with districts performance contracts signed between the mayor and President of Republic. The total is 119 staffs which subdivided to 36 district employees (working at Nyamasheke District head office), 15 executive secretaries from 15 sectors of Nyamasheke District and 68 executive secretaries of cells. As populations seem to be large, the researcher has applied sampling formula to reduce the size of the population to sample size.

\subsection{Sampling methods and techniques}

Yamane (1967:886) provides a simplified formula to calculate sample sizes. This formula was used to calculate the sample sizes from 119 Nyamasheke District Staff (as total population) to 54 staff of Nyamasheke District (sample size).

$$
n=\frac{N}{1+N *(e)^{2}}=\frac{119}{1+119 *(0.1)^{2}}=54.33 \approx 54
$$

Where $\mathrm{N}$ represents the total population, $\mathrm{n}$ signify sample size, e confidence level (which is 90\% for this study). Sampling technique adopted is non-probability sampling "purposive sampling" which stand from the fact that the researcher chose to staff from different departments. The reason why at sector and cells level only executive secretary was selected as the target population.

\subsection{Data collection tools}

This study has used both primary and secondary data for assessing validity of its hypotheses and objectives. Secondary data was collected using a documentary review (District Development Strategy Report and District Imihigo Reports 2014-2020). Primary data were 


\section{International Journal of Social Sciences and Management Review}

collected using a questionnaire, and this questionnaire was filled by the researcher as an output of face to face talks between the researcher and the sampled respondent.

\subsection{Study objectives}

This study focuses on four angles:

1. Evaluate the quality of Nyamasheke District Performance contracts and staff individual performance contracts (pillars, outcome, output, and indicators);

2. Evaluate the level of imihigo performance in last 6 years (2014 to 2019) at all sectors of socio-economic development.

3. To assesses socio-economic development of Nyamasheke District from 2014 to 2019; and

4. To evaluate the significant correlation between performance contract and socioeconomic development of Nyamasheke District.

\subsection{The hypothesis of the study}

This study focuses on four hypotheses:

H01: Nyamasheke District performance contracts (as a whole) and individual staff performance contracts are not well formulated.

H02: Imihigo signed by District in last 6 years (2014-2019) on socio-economic development were poorly performed.

H03: From 2014 to 2019 Nyamasheke District has ensured poor performance in socioeconomic development.

H04: There is no significant correlation between performance contracts and socio-economic development of Nyamasheke District.

\subsection{Data analysis}

As explained above, this study was analyzed in both primary and secondary data. H01, H02 and $\mathrm{H} 03$ were tested using secondary data while H04 was tested using primary data. Secondary data were analyzed using descriptive statistics and primary data for testing Hypothesis H04 was used bivariate correlation analysis.

$$
r_{x y}=\frac{n \sum x_{i} y_{i}-\sum x_{i} \sum y_{i}}{\sqrt{n \sum x_{i}^{2}-\left(\sum x_{i}\right)^{2}} \sqrt{n \sum y_{i}^{2}-\left(\sum y_{i}\right)^{2}}}
$$

rxy $=$ Pearson $r$ correlation coefficient between $\mathrm{x}$ and $\mathrm{y}$

$\mathrm{n}=$ number of observations

$\mathrm{xi}=$ value of $\mathrm{x}$ (for ith observation) 


\section{International Journal of Social Sciences and Management Review}

yi = value of $y$ (for ith observation)

$\mathrm{r}$ is ranked between \pm 1 and ranked into a various category based on the level strong, weak or moderate positive or negative correlation. This correlation may be statistically significant once Sig.(2-tailed) is less or equal to 0.05 .

\subsection{FINDINGS OF THE STUDY}

\subsection{Background of respondents Nyamasheke District Staffs}

Respondents were classified based on their working level (groups), sex, ages and years of experience as employees in Nyamasheke District. Respondents characteristics facilitate to understand the value of findings from them. Where performance, ideas, and reasoning capacity as well as working ability and role in the society vary from one person to another with the interaction of the working group or level, ages, sex, and experience. For example, if other factors remain constantly experienced employees are good performers (these with more years of experience at work).

Table 1: Characteristics of Respondents

\begin{tabular}{lcc}
\hline Characteristics of Respondents & Frequency & Percent \\
\hline Staff category & 16 & 29.6 \\
District Staffs (working at Office) & 7 & 13.0 \\
Executive secretary at Sector Office & 31 & 57.4 \\
Executive secretary at Cells Office & 18 & \\
\hline Sex & 36 & 33.3 \\
Females & & 66.7 \\
Males & 7 & 13.0 \\
\hline Ages interval & 16 & 29.6 \\
Between 21 to 31 years & 21 & 38.9 \\
Between 31 to 41 years & 9 & 16.7 \\
Between 41 to 51 years & 1 & 1.9 \\
Between 51 to 61 years & & \\
61 years and above & 4 & 7.4 \\
\hline Years of experience (in Nyamasheke) & 33 & 61.1 \\
Less than 3 years & 10 & 18.5 \\
Between 3 to 5 years & 7 & 13.0 \\
Between 5 to 7 Years & $\mathbf{5 4}$ & \\
7 years and more & &
\end{tabular}

Source: Primary data, 2020

Table 1 shows that from 54 assessed Nyamasheke District staffs 16 (29.6\%) were staffs working in the head office of Nyamasheke District, 7 (13\%) were sampled from Executive secretary of sectors and $31(57.4 \%)$ were sampled from 68 cells executive secretary in Nyamasheke District. By sex gender balance in Nyamasheke District was respected where from 54 sampled district staffs 18 (33.3\%) were females and $36(66.7 \%)$ males. By age 


\section{International Journal of Social Sciences and Management Review}

Nyamasheke District is experienced mature staff where most of them 21 (38.9\%) aged between 41 to 51 years old, followed by $16(29.6 \%)$ aged between 31 to 41 years old, 9 (16.7\%) aged between 51 to 61 years old, $7(13 \%)$ aged between 21 to 31 years old and 1 (1.9\%) aged 61 years old and above. By experience Nyamasheke District staff are experienced where most of them $33(61.1 \%)$ experienced between 3 to 5 years, $10(18.5 \%)$ experienced between 5 to 7 years, $7(13 \%)$ experienced 7 years and more and $4(7.4 \%)$ are experienced less than 3 years.

\subsection{Test of H01}

H01: Nyamasheke District performance contracts (as a whole) and individual staff performance contracts are not well formulated.

The researcher has observed and assessed performance contracts signed by Nyamasheke district from 2014/2015 to 2018/2019 and find that, they are in line with government priorities. They are all developed as follows: Pillar, outcome, output and per each output a number of indicators are defined where per each a baseline is well defined, source, targets, responsible person and estimated budget. Based on this observation and as it's in line with government priorities the $\mathrm{H} 01$ is rejected.

Table 2: Nyamasheke District Imihigo (performance Contracts): Socio-Economic Development Indicators

\begin{tabular}{|c|c|}
\hline Outputs (Under priority area/ sector/ Pillars) & Indicator \\
\hline \multicolumn{2}{|l|}{ ECONOMIC TRANSFORMATION PILLAR } \\
\hline \multicolumn{2}{|c|}{ SECTOR: AGRICULTURE } \\
\hline \multicolumn{2}{|c|}{ Outcome 1: Increased productivity for priority crops on consolidated sites } \\
\hline \multirow{3}{*}{$\begin{array}{l}\text { Output 1.1: Agricultural productivity through land use and } \\
\text { inputs use increased }\end{array}$} & $\begin{array}{l}\text { Number of ha consolidated under priority } \\
\text { crops }\end{array}$ \\
\hline & $\begin{array}{l}\text { MT of improved seeds timely delivered } \\
\text { and used by farmers }\end{array}$ \\
\hline & $\begin{array}{l}\text { MT of fertilizers timely delivered and used } \\
\text { by farmers }\end{array}$ \\
\hline $\begin{array}{l}\text { Output 1.2: Effective and efficient irrigation developed under an } \\
\text { Integrated Water Resource Management (IWRM) framework }\end{array}$ & $\begin{array}{l}\text { Number of Ha under Small Scale Irrigation } \\
\text { (SSIT) developed } \\
\end{array}$ \\
\hline \multirow{2}{*}{ Output 1.3: Area of land protected against erosion increased } & $\begin{array}{l}\text { Number of ha of radical terraces } \\
\text { constructed (cumulative). }\end{array}$ \\
\hline & $\begin{array}{l}\text { Number of Ha of progressive terraces } \\
\text { constructed (cumulative). }\end{array}$ \\
\hline \multicolumn{2}{|l|}{ Outcome 2: Post-harvest infrastructures increased } \\
\hline Output 2.1: Post-harvest drying facilities constructed & $\begin{array}{l}\text { Number of Rice drying facilities } \\
\text { constructed }\end{array}$ \\
\hline \multicolumn{2}{|l|}{ Outcome 3: Increased animal productivity } \\
\hline \multirow[b]{2}{*}{ Output 3.1: Genetics for cows improved } & Number of cows inseminated (cumulative) \\
\hline & $\begin{array}{l}\text { Number of Al born calves registered } \\
\text { (cumulative) }\end{array}$ \\
\hline Output 3.2: Livestock vaccinated against diseases & Number of cows vaccinated against \\
\hline
\end{tabular}




\section{International Journal of Social Sciences and Management Review}

Volume: 03, Issue: 04 "July - August 2020"

ISSN 2582-0176

\begin{tabular}{|c|c|}
\hline \multirow[t]{2}{*}{ Outputs (Under priority area/ sector/ Pillars) } & Indicator \\
\hline & diseases \\
\hline \multicolumn{2}{|l|}{ Outcome 4: Increased cash crops production } \\
\hline Output 4.1: Tea production increased & Quantity of dry tea produced (T) \\
\hline Output 4.2: Coffee production Increased & Quantity of washed Coffee produced (MT) \\
\hline Output 4.3: Vegetables production increased & Area of vegetables planted $(\mathrm{Ha})$ \\
\hline \multicolumn{2}{|c|}{ SECTOR: PRIVATE SECTOR DEVELOPMENT \& YOUTH EMPLOYMENT } \\
\hline \multicolumn{2}{|c|}{ Outcome 5: Increased productive Jobs through entrepreneurship and business development } \\
\hline Output 5.1: Productive jobs increased & $\begin{array}{l}\text { Number of productive jobs created } \\
\text { (cumulative) }\end{array}$ \\
\hline $\begin{array}{l}\text { Output 5.2: } \\
\text { New TVET graduates accessing start up toolkit facilities increased }\end{array}$ & $\begin{array}{l}\text { Number of TVET graduates and } \\
\text { cooperatives received start up toolkit } \\
\text { facilities }\end{array}$ \\
\hline $\begin{array}{l}\text { Output 5.3: } \\
\text { Start -up and Micro, Small and Medium Enterprises (MSMEs) } \\
\text { coached to access finance }\end{array}$ & $\begin{array}{l}\text { Number of start-up and existing MSMEs } \\
\text { coached to access finance (Cumulative) }\end{array}$ \\
\hline \multirow[t]{2}{*}{ Output 5.4: Markets Infrastructure developed } & $\begin{array}{l}\text { Execution rate of Rugari Cross Border } \\
\text { Market }\end{array}$ \\
\hline & Number of selling point constructed \\
\hline \multicolumn{2}{|l|}{ SECTOR: FINANCIAL SECTOR DEVELOPMENT } \\
\hline \multicolumn{2}{|l|}{ Outcome 6: Enhanced EJO HEZA Long Term Savings } \\
\hline \multirow{2}{*}{$\begin{array}{l}\text { Output 6.1: } \\
\text { Subscriptions and Savings increased through Ejo Heza Long Term } \\
\text { Saving Scheme }\end{array}$} & Number of members enrolled (cumulative) \\
\hline & Amount of money saved (cumulative) \\
\hline \multicolumn{2}{|l|}{ SECTOR: ENERGY (Connections to Productive Use Areas) } \\
\hline \multicolumn{2}{|l|}{ Outcome 7: Electricity access to Productive uses increased } \\
\hline $\begin{array}{l}\text { Output 7.1: Productive use areas connected to electricity (on } \\
\text { grid) }\end{array}$ & $\begin{array}{l}\text { Number of Productive use areas connected } \\
\text { to electricity (cumulative) }\end{array}$ \\
\hline \multicolumn{2}{|l|}{ SECTOR: ENVIRONMENT AND NATURAL RESOURCES } \\
\hline \multicolumn{2}{|c|}{ Outcome 8: Increased sustainability and profitability of forestry management } \\
\hline Output 8.1: Forest coverage maintained and increased & Number of ha of land under agro forestry \\
\hline Output 8.2: Fruit trees planted & Number of fruit trees planted \\
\hline
\end{tabular}

Source: (Nyamasheke, 2019)

\subsection{Test of $\mathrm{HO2}$}

H02: Imihigo signed by District in last 6 years (2014-2019) on socio-economic development were poorly performed.

To test this, the researcher has analyzed the performance of Nyamasheke District vis a vis another district in Imihigo. The figure below gives more clarifications.

Figure 2: Nyamasheke District Overall Imihigo Evaluation 2014/15 to 2018/19 


\section{International Journal of Social Sciences and Management Review}

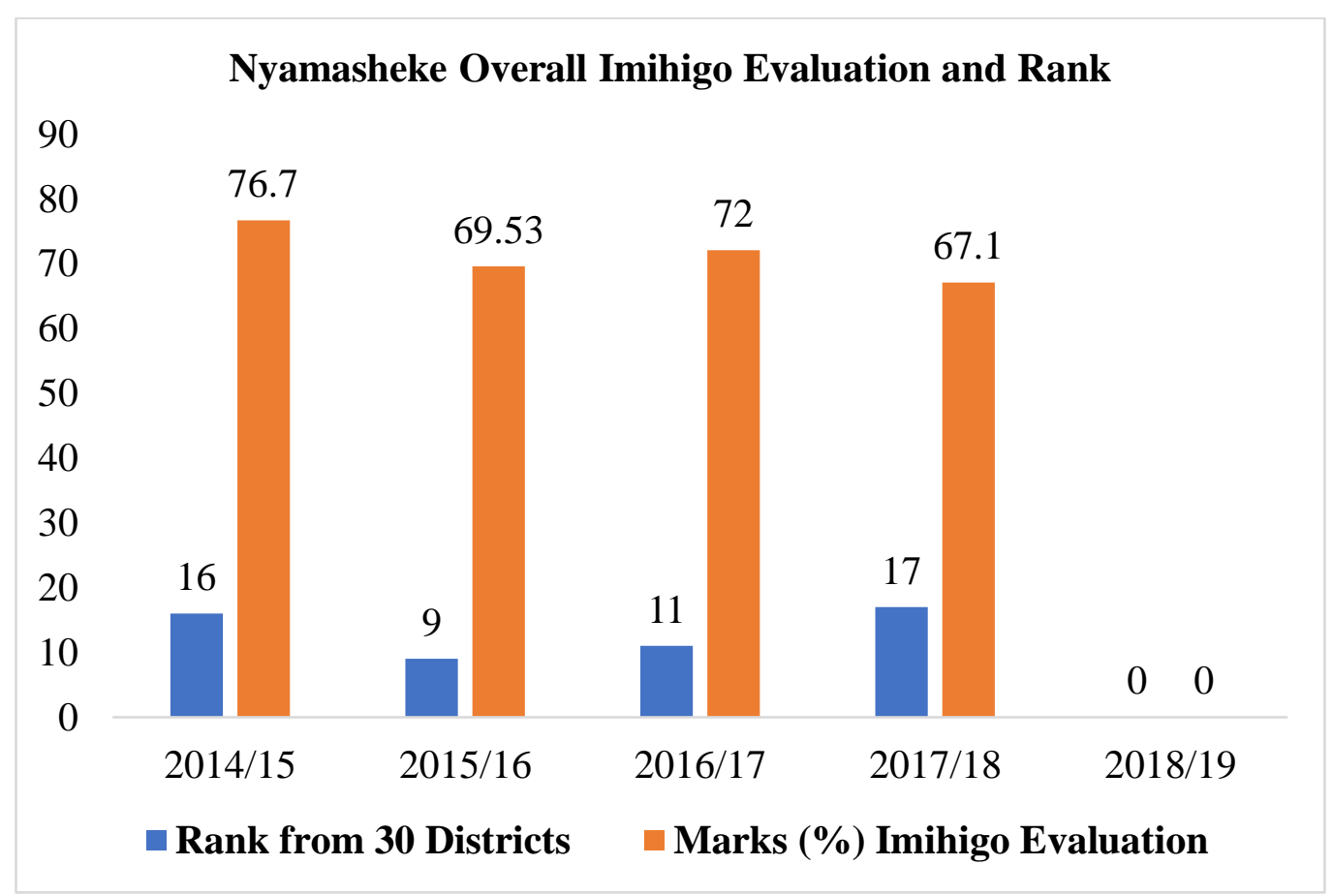

Source: (Office of the Prime Minister, 2020)

As seen in Figure 2, Nyamasheke District does not have consistency in Imihigo performance, always vary from one year to another. In general, from $2014 / 15$ there is a descending rate from $76.7 \%$ to $67.1 \%$ of $2017 / 18$ because $2018 / 19$ evaluation was not conducted at a national level. The position always remains above 10th position in 30 districts. This mark middle performance while on individual Imihigo performance this district got 8th position with $80.3 \%$ marks in 2016/17. In the same year (2017/18) social-economic pillar Nyamasheke also has got a good position (5th) with $80.7 \%$ marks. Based on that, the researcher stands on findings and conclude that $\mathrm{H} 02$ is not accepted.

\subsection{Test of $\mathrm{HO3}$}

H03: From 2014 to 2019 Nyamasheke District has ensured poor performance in socioeconomic development.

Secondary data assessed on socio-economic performance of Nyamasheke District were captured from EICV5 (NISR, 2018). This report shows that Nyamasheke district has $69.3 \%$ poverty incidence rate, $41.5 \%$ extreme poverty rate, $45.1 \%$ labour force participation rate, $34.4 \%$ unemployment rate, $17.3 \%$ percentage of land under consolidation, $70.3 \%$ percentage of land protected against soil erosion, $2.1 \%$ percentage of land under irrigation, $22.1 \%$ of households using electricity, $89 \%$ households using an improved water source, $34 \%$ of stunted children under five years, $1.2 \%$ households owning a computer, $69.9 \%$ literacy of population aged 15 and above, $80 \%$ of adult financial inclusion and $28.7 \%$ of households with rainwater catchment systems. All these indicators lead to the ranking of Nyamasheke District on the 30th Position on poverty ranking (the last among 30 Districts) or the poorest among others. Thus, due to that, the H03 is accepted.

\subsection{Test of $\mathrm{HO4}$}




\section{International Journal of Social Sciences and Management Review}

Volume: 03, Issue: 04 "July - August 2020"

ISSN 2582-0176

H04: There is no significant correlation between performance contracts and socio-economic development of Nyamasheke District.

Table 3: Effectiveness of Imihigo (performance Contract) in Nyamasheke District

\begin{tabular}{|c|c|c|c|c|c|c|c|c|c|}
\hline \multirow{2}{*}{ Items Assessed } & \multicolumn{2}{|c|}{ SA } & \multicolumn{2}{|c|}{ A } & \multicolumn{2}{|c|}{ D } & \multirow{2}{*}{ Mean } & \multirow{2}{*}{ Stdv } & \multirow{2}{*}{ Rank } \\
\hline & fi & $\%$ & $\mathrm{fi}$ & $\%$ & fi & $\%$ & & & \\
\hline Nyamasheke District Set & & & & & & & & & \\
\hline $\begin{array}{l}\text { Imihigo and individual } \\
\text { imihigo based on National } \\
\text { Priorities }\end{array}$ & 54 & 100.0 & 0 & 0.0 & 0 & 0.0 & 5.000 & 0.00 & $\begin{array}{c}\text { Strong } \\
\text { Homogeneity }\end{array}$ \\
\hline $\begin{array}{l}\text { Imihigo are settled with a } \\
\text { respect of general format } \\
\text { (Pillar, Sector, Outcome, } \\
\text { Output and Indicators) }\end{array}$ & 45 & 83.3 & 9 & 16.7 & 0 & 0.0 & 4.833 & 0.14 & $\begin{array}{c}\text { Strong } \\
\text { Homogeneity }\end{array}$ \\
\hline $\begin{array}{l}\text { Each Indicator is defined } \\
\text { with clear baseline and } \\
\text { Target }\end{array}$ & 50 & 92.6 & 4 & 7.4 & 0 & 0.0 & 4.926 & 0.07 & $\begin{array}{c}\text { Strong } \\
\text { Homogeneity }\end{array}$ \\
\hline $\begin{array}{l}\text { Activities are well defined } \\
\text { in Imihigo with significant } \\
\text { calculated budget and } \\
\text { clear on responsibility for } \\
\text { each staff or institution }\end{array}$ & 12 & 22.2 & 30 & 55.6 & 12 & 22.2 & 3.778 & 1.08 & $\begin{array}{c}\text { Strong } \\
\text { Heterogeneity }\end{array}$ \\
\hline $\begin{array}{l}\text { Imihigo Evaluation is being } \\
\text { conducted with everyone } \\
\text { contribution and everyone } \\
\text { is happy on rating }\end{array}$ & 3 & 5.6 & 40 & 74.1 & 11 & 20.4 & 3.648 & 0.76 & $\begin{array}{c}\text { Strong } \\
\text { Heterogeneity }\end{array}$ \\
\hline
\end{tabular}

Source: Primary Data 2020

Table 3 shows that Nyamasheke District Set Imihigo and individual imihigo based on National Priorities (100\% strongly agreed), Imihigo are settled with respect of general format (Pillar, Sector, Outcome, Output and Indicators) (83.3\% strongly agreed and $16.7 \%$ agreed), Each Indicator is defined with clear baseline and Target $(92.6 \%$ strongly agreed and $7.4 \%$ agreed), Activities are well defined in Imihigo with a significant calculated budget and clear on responsibility for each staff or institution (22.2\% strongly agreed, 55.6\% agreed and $22.2 \%$ disagreed) and Imihigo Evaluation is being conducted with everyone contributes and everyone is happy on rating (5,6\% strongly agreed, $74.1 \%$ agreed and $20.4 \%$ disagreed).

Table 4: Socio-economic performance of Nyamasheke District

\begin{tabular}{lccccccccc}
\hline \multirow{2}{*}{ Items Assessed } & \multicolumn{2}{c}{ SA } & \multicolumn{2}{c}{ A } & \multicolumn{2}{c}{ D } & \multirow{2}{*}{ Mean } & Stdv & Rank \\
\cline { 2 - 7 } & $\mathbf{f i}$ & $\mathbf{\%}$ & $\mathbf{f i}$ & $\mathbf{\%}$ & $\mathbf{f i}$ & $\mathbf{\%}$ & & & \\
\hline $\begin{array}{l}\text { Nyamasheke District has } \\
\text { made good performance in } \\
\text { infrastructure development }\end{array}$ & 17 & 31.5 & 27 & 50.0 & 10 & 18.5 & 3.944 & 1.07 & $\begin{array}{c}\text { Strong } \\
\text { Heterogeneity }\end{array}$ \\
$\begin{array}{l}\text { Nyamasheke District has } \\
\text { made good effort in poverty } \\
\text { reduction }\end{array}$ & 2 & 3.7 & 13 & 24.1 & 39 & 72.2 & 2.593 & 0.96 & $\begin{array}{c}\text { Moderate } \\
\text { Heterogeneity }\end{array}$
\end{tabular}




\section{International Journal of Social Sciences and Management Review}

Volume: 03, Issue: 04 "July - August 2020"

ISSN 2582-0176

\begin{tabular}{|c|c|c|c|c|c|c|c|c|c|}
\hline \multirow{2}{*}{ Items Assessed } & \multicolumn{2}{|c|}{ SA } & \multicolumn{2}{|c|}{ A } & \multicolumn{2}{|c|}{ D } & \multirow{2}{*}{ Mean } & \multirow{2}{*}{ Stdv } & \multirow{2}{*}{ Rank } \\
\hline & $\mathrm{fi}$ & $\%$ & $\mathrm{fi}$ & $\%$ & $\mathrm{fi}$ & $\%$ & & & \\
\hline $\begin{array}{l}\text { Nyamasheke District has } \\
\text { made good performance in } \\
\text { improved health services } \\
\text { and sanitation to its } \\
\text { households }\end{array}$ & 20 & 37.0 & 14 & 25.9 & 20 & 37.0 & 3.630 & 1.75 & $\begin{array}{c}\text { Strong } \\
\text { Heterogeneity }\end{array}$ \\
\hline $\begin{array}{l}\text { Nyamasheke District is a } \\
\text { good performer in socio- } \\
\text { economic development } \\
\text { compared to other Districts }\end{array}$ & 2 & 3.7 & 7 & 13.0 & 45 & 83.3 & 2.370 & 0.73 & $\begin{array}{c}\text { Moderate } \\
\text { Heterogeneity }\end{array}$ \\
\hline $\begin{array}{l}\text { Nyamasheke Districts staff } \\
\text { are good enough to help } \\
\text { the district to achieve its } \\
\text { targets }\end{array}$ & 5 & 9.3 & 40 & 74.1 & 9 & 16.7 & 3.759 & 0.71 & $\begin{array}{c}\text { Strong } \\
\text { Heterogeneity }\end{array}$ \\
\hline
\end{tabular}

Source: Primary Data 2020

As seen from table 4, Nyamasheke District has made a good performance in infrastructure development (31.5\% strongly agreed, $50 \%$ agreed and $18.5 \%$ disagreed), Nyamasheke District has made a good effort in poverty reduction (3.7\% strongly agreed, $24.1 \%$ agreed and $72.2 \%$ disagreed), Nyamasheke District has made a good performance in improved health services and sanitation to its households (37\% strongly agreed, 25.9\% agreed and 37\% disagreed), Nyamasheke District is a good performer in socio-economic development compared to other districts (3.7\% strongly agreed, $13 \%$ agreed and $83.3 \%$ disagreed) and Nyamasheke Districts staff are good enough to help the district to achieve its targets $(9.3 \%$ strongly agreed, $74.1 \%$ agreed and $16.7 \%$ disagreed).

Table 5: Bivariate analysis

Correlations

\begin{tabular}{|ll|c|c|}
\hline \multicolumn{2}{|l|}{$\begin{array}{l}\text { Tested Indicators representing Independent and } \\
\text { Dependent Variable }\end{array}$} & $\begin{array}{c}\text { Performance } \\
\text { Contracts }\end{array}$ & $\begin{array}{c}\text { Socio-Economic } \\
\text { Development }\end{array}$ \\
\hline Pearfor & 1 & $.210^{* *}$ \\
& $\begin{array}{l}\text { Correlation } \\
\text { Sig. (2-tailed) }\end{array}$ & $\mathbf{5 4}$ & .001 \\
& $\mathbf{N}$ & $\mathbf{5 4}$ \\
& Pearson \\
Correlation & $.210^{* *}$ & 1 \\
Socio-Economic Development & Sig. (2-tailed) & .001 & \\
& $\mathbf{N}$ & $\mathbf{5 4}$ & $\mathbf{5 4}$ \\
\hline
\end{tabular}

**. Correlation is significant at the 0.01 level (2-tailed).

Source: Primary data 2020

Table 6 present bivariate correlation analysis of primary data (perception of respondents on items assessed). Pearson correlation ( $r$ ) is 0.210 meaning that, there is a weak positive correlation between imihigo (performance contract) and socio-economic development. Sig. 


\section{International Journal of Social Sciences and Management Review}

(2-tailed) is equal to 0.001 showing that, thus correlation resulted or signified by $\mathrm{r}$ is statistically significant. Thus, the researcher concludes that H04 is not accepted.

\subsection{CONCLUSION}

This study was conducted to assess the significance Performance Contract (Imihigo) on socio-economic development of Rwanda: A case of Nyamasheke District (2014-2019). The study findings (secondary data) have been shown that 100\% Nyamasheke district respect the format of Imihigo, Nyamasheke District also use national priorities, pillars for setting outcome, outputs, indicators sector by sector. In other case, indicators are well defined with clear baseline, targets, responsibilities and budget. These findings were used by the researcher to reject H01 "Nyamasheke District performance contracts (as a whole) and individual staff performance contracts are not well formulated". The assessment of H02 "Imihigo signed by District in last 6 years (2014-2019) on socio-economic development was poorly performed" also have revealed that Nyamasheke District ensures moderate performance in terms of imihigo evaluation. On the case of the economic pillar, this district was ranked good with more than $80 \%$ marks the same case for individual performance. This was resulted in the authority to the researcher for not accepting this hypothesis. Assessment again of secondary data has shown that Nyamasheke district is a poor performer in the real economy (the researcher use this as the difference of paper evaluation and field visit (visiting households one by one) as made by NISR through EICV5 and find that Nyamasheke District ranked the last (30th) in 30 districts in poverty reduction. Due to that, the researcher has accepted the H03. For the H04, the researcher has tested primary data (finings from the field) on the perception of respondents (District staffs) on both variables). Pearson correlation (r) is 0.210 meaning that, there is a weak positive correlation between imihigo (performance contract) and socio-economic development. Sig. (2-tailed) is equal to 0.001 showing that, thus correlation resulted or signified by $r$ is statistically significant. Thus, the researcher concludes that H04 is not accepted. Thus, evaluation of Imihigo may rank a district or a staff on good rank while on field people are suffering. A good ranking should be delivered from households looking changes they got in their living conditions with the support of local government authorities. Other case performance contracts have a little (weak positive correlation) on socio-economic development, it counts only $21 \%$ while the remaining $79 \%$ is from other factors not captured by this study.

\section{References}

Bruno. (2012). Rwanda:performance contracts(imihigo). Kigali: Overseas Developmnet Institute.

Cohen. (2003). Applied multiple regression/correlation analysis for the behavioral sciences. Hillsdale, NJ: Lawrence Erlbaum Associates.

Daniel et al. (2014 ). The secret ingredient in Rwanda's efforts to rebuild its nation after the violence of genocide: How Tradition Remade Rwanda. https://foreignpolicy.com/2014/01/28/how-tradition-remade-rwanda/ Retrieved on 4th February 2020. 


\section{International Journal of Social Sciences and Management Review}

Volume: 03, Issue: 04 "July - August 2020"

ISSN 2582-0176

Draper, Norman R.; van Nostrand; R. Craig. (1979). Ridge Regression and James-Stein Estimation: Review and Comments. JSTOR: Technometrics. 21 (4): 451-466. doi: $10.2307 / 1268284$.

Evarlyn. (2015). The importace of setting performance targets on service delivery in performance contracting at the ministry of tourism, Kenya. Catholic University of Eastern Africa Nairobi Kenya.

Habamenshi et al. (2019). The Contribution of Imihigo on Socio-Economic Development in Rwanda: A Case of Gakenke District (2013-2018). Retrived on 28th January 2020: https://www.researchgate.net/publication/330958798_The_Contribution_of_Imihigo_ on_Socio-Economic_Development_in_Rwanda_A_Case_of_Gakenke_District_20132018_Vedaste_Habamenshi_Sylvie_Nibeza_Sebastien_Gasana_Zephyrin_Shamukiga _Ntakirutimana.

IPAR. (2016). Evaluating performance contracts (Imihigo) that improve the lives of Rwandans. Kigali: IPAR-Rwanda.

IPAR. (2017). Imihigo Evaluation FY2016/2017:FinalReport. Kigali: Office of the Prime Minister.

Jonathan Rothbaum. (2018). Cooperatives in a Global Economy: Key Economic Issues, Recent Trends, and Potential for Development. IZA Policy Paper No. 68.

Kihara. (2013). Factors affecting the implementation of strategic performance measurement system of parastatals in Kenya: A case study of the Kenya Rural Roads Authority. . Journal of Arts and entrepreneurship, Vol. 1, Issue No. 2.

Kogei et al. (2013). he effects of performance contracting on service delivery in the public sector; Focus on the supply chain department of Moi teachingand Referral Hospital, Kenya. International Journal of Business and Commerce, Vol. 2, No.6: Feb 2013[1219].

Letangule. (2012). ffect of performance contract on organizational performance; Thecase study of Kenya's ministry of education. International Journal of Management and Business Studies, Issue No. 3.

Mann. (2010). Make Millions and Make Change!: Secrets to Business and Personal Success.USA, Makemillion.com .

MINECOFIN. (2018). National Strategy for Transformation (NST1). Kigali: Ministry of Economics and Finance.

Murangwa. (2012). Households Living Condition Survey EICV 3. kIGALI: National Institute of Statistics of Rwanda (NISR).

Murangwa. (2014). Rwanda Population and Housing Census 2012. Kigali: National Institute of Statistics of Rwanda.

NISR. (2018). Fith Household Living Condition Survey (EICV5 2016/17). Kigali: National Institute of Statistics of Rwanda. 


\section{International Journal of Social Sciences and Management Review}

NISR. (2018). Imihigo Evaluation Report 2017/2018 . Kigali: The Republic of Rwanda.

Nyamasheke. (2019). Nyamasheke District Imihigo Financial Year 2019/2020. Nyamasheke: Nyamasheke District.

Odi. (2012). Budget Strengthening Initiative. Bruno Versailles: Overseas Development Institute.

Office of the Prime Minister. (2020). District Imihigo Evaluation Reports FY 2014/15 to 2018/19. Kigali: nstituteof Policy Analysis and Research-Rwanda (IPAR-Rwanda).

RDB. (2019). Rwanda Economic Transformation Outlook 2018. Kigali: Rwanda Developmnet Board.

Simeone. (2017). Evaluating performance contracts (Imihigo) that improve the lives of Rwandans. Kigali : World Bank.

Simiyu. (2012). erformance contract as a tool for improving performance in local authorities in Kenya. Thesis submitted to Jomo Kenyatta University, Nairobi, Kenya.

Solomon. (2012). Effects of Performance Contract on Organization Performance: The Case Study of Kenya's Ministry of Education. Jomo Kenyatta University of Agriculture and Technology (JKUAT), Nairobi, Kenya. 